\title{
Studi Awal Desain Hull USV (Unmanned Surface Vehicle) untuk Pengukuran Batimetri di Perairan Tenang
}

\author{
ZULFIKAR BANU AZMAR, NI MADE RAI RATIH CAHYA PERBANI
}

\author{
Jurusan Teknik Geodesi \\ FTSP - Institut Teknologi Nasional, Bandung \\ Email: dolunxss@gmail.com
}

\begin{abstract}
ABSTRAK
USV batimetri adalah wahana apung tanpa awak berdimensi kecil dan mudah dibawa untuk pengukuran batimetri. Penelitian ini bertujuan untuk mendesain bentuk hull USV yang stabil untuk keperluan survei batimetri di perairan tenang. Bentuk hull yang didesain berupa monohull yang dioperasikan di perairan tawar, hanya mempertimbangkan kestabilan statik vertikal untuk gerakan heave (yang disebabkan oleh bobot total USV) dan roll sudut kecil tanpa pengaruh angin dan arus. Hull USV didesain dengan panjang 1,64 meter; lebar 0,52 meter; dan tinggi total 0,26 meter di mana dua pertiga hull bagian bawah buritan berbentuk $U$ dan sepertiga hull bagian bawah haluan berbentuk V. Draft rencana 0,08 $\mathrm{m} ; 0,12 \mathrm{~m} ; 0,16 \mathrm{~m}$ memiliki kestabilan statik vertikal yang baik dengan koefisien blok berkisar 0,68-0,71 sehingga dikategorikan sebagai kapal yang didesain bukan untuk kapal cepat. Bobot USV beserta muatan direkomendasikan antara 36 - $83 \mathrm{~kg}$. Dari dimensi, bobot, dan koefisien blok yang cukup besar hull yang didesain dapat dikategorikan sebagai wahana apung tanpa awak berkecepatan rendah sehingga cocok untuk keperluan survei batimetri.
\end{abstract}

Kata kunci: USV batimetri, heave, roll sudut kecil, draft.

\begin{abstract}
Bathimetric USV is a portable unmanned vehicle with small dimension which is capable of carrying out bathymetric measurements. This study is intended to design the stable USV hull for bathymetric surveys in calm waters. The hull is designed as a monohull and will be operated in freshwater, only consider the vertical static stability for heave motion (caused by the total weight of USV) and small angle roll without the influence of wind and currents. USV hull is designed with 1.64 meters length, 0.52 meters breadth, and 0.26 meters depth which has $U$-shaped at two-thirds of the aft hull bottom and U-shaped at one-third of fore hull bottom. The drafts plan of 0,08 $\mathrm{m}, 0,12 \mathrm{~m}$, and 0,16 $\mathrm{m}$ have good vertical static stability with block coefficient from 0.68 to 0.71 , so the designed USV is not classified as a fast ship. USV total weight is recommended between 36 to $83 \mathrm{~kg}$. From the dimensions, weight, and large block coefficient the designed USV hull can be categorized as a unmanned vessel with low speed. Therefore, it is suitable for bathymetric USV.
\end{abstract}

Keywords: bathimetric USV, heave, small angle roll, draft

Reka Geomatika - 42 


\section{PENDAHULUAN}

Menurut Duranti dan Romano (2012), Unmanned Surface Vehicle (USV) batimetri adalah wahana tanpa awak berdimensi kecil dan mudah dibawa untuk pengukuran batimetri yang dapat dikontrol baik oleh operator maupun sepenuhnya tanpa operator. USV merupakan solusi inovatif untuk keselamatan manusia jika kegiatan berlangsung di tempat yang berbahaya, tidak menyebabkan pencemaran lingkungan, mengurangi jumlah operator yang terlibat sehingga kegiatan survei menjadi lebih fleksibel dan dengan dimensi yang kecil akan membuat kemudahan dalam penanganan, konsumsi daya, dan rendah biaya operasional. Meskipun pada saat ini sebagian besar pengukuran batimetri digunakan untuk mengukur kedalaman laut ada juga aplikasi untuk di danau, waduk, sungai, dan cekungan air tawar lainnya. Contohnya pengukuran untuk pemetaan bawah air pembangkit listrik tenaga air, infrastruktur tersebut perlu dipantau secara berkala. Hal ini sebenarnya sangat penting untuk mengetahui total volume yang tersedia dan kedalaman cekungan. Kegiatan ini akan sangat beresiko untuk dilakukan dengan menggunakan kapal berawak dengan jarak yang sangat dekat dengan gerbang bendungan. Meskipun teknologi modern tidak memerlukan kapal besar, namun kapal berdimensi kecilpun masih harus dikendalikan oleh juru mudi kapal serta masih memerlukan surveyor batimetri. Di samping itu, untuk daerah survei yang berlokasi di daerah yang sangat terpencil atau tidak bisa diakses kendaraan akan lebih mempersulit pelaksanaan survei. Selain itu daerah perairan yang dangkal akan menimbulkan resiko patahnya baling-baling dan kemudi kapal. USV menjadi alternatif yang baik untuk kesulitan yang dipaparkan, kapal robot yang dapat menggantikan awak manusia dan secara otomatis menyelesaikan misi. Hal ini terbukti menguntungkan dan mempengaruhi seluruh proses, baik dari segi efisiensi, kemudahan penanganan, biaya, dan keamanan khususnya untuk daerah yang terkontaminasi.

Saat ini penelitian USV di Indonesia mulai berkembang, tetapi perkembangan tersebut didominasi untuk keperluan militer sebagai kapal tanpa awak penjaga perairan Indonesia. USV untuk keperluan sipil di antaranya adalah Geomar Autopilot Survey Boat yang dikembangkan oleh PT. Robo Marine Indonesia di Bandung yang merupakan sebuah USV untuk survei hidrografi yang dikendalikan dari jarak jauh menggunakan remote control. Dengan dimensi Geomar (panjang 1,4 m; lebar 0,4 m; dan depth 0,4 m) memberikan kemudahan bagi surveyor hidrografi untuk melakukan survei batimetri perairan dangkal di daratan, seperti survei jarak jauh pada kanal, danau, kolam, reservoir, dan sungai. Perbani (2014) dalam penelitannya telah membuat sebuah purwarupa USV. Penelitian tersebut bertujuan untuk membangun suatu sistem penentuan posisi dan navigasi berbasiskan sistem USV sebagai upaya awal dalam pengembangan hidrografi di Institut Teknologi Nasional, Bandung. Pembuatan USV tersebut didasarkan pada Model Windrush II Airboat yang direkonstruksi tiga dimensi secara dijital dari foto model tersebut menggunakan teknologi Reverse Engineering Metode Close Range Photogrammetry yang diperbesar dua kali. USV yang dihasilkan diujicobakan di Danau Saguling. Berdasarkan penelitian didapatkan bahwa USV masih memerlukan modifikasi pada bagian lambung (hull) USV karena masih terjadi ketidakstabilan saat dioperasikan. Hal tersebut berpengaruh pada resiko data yang dihasilkan dan tenggelamnya USV.

Dalam pembuatan desain kapal terdapat beberapa langkah yang dilakukan, di antaranya adalah melakukan riset terhadap desain kapal yang aman beroperasi di perairan dengan kebutuhan yang direncanakan. Aman di sini berarti memiliki stabilitas yang baik walaupun membawa beban di kondisi perairan yang ekstrem. 
Hasil akhir yang diharapkan dari penelitian ini berupa desain lambung kapal yang optimal untuk survei batimetri, namun masih untuk di perairan tenang. Kestabilan sebuah USV survei batimetri ditentukan oleh hull yang memiliki stabilitas yang baik walaupun membawa beban alat ukur batimetri dan aman beroperasi di perairan dengan kebutuhan yang direncanakan karenanya penelitian ini ditujukan untuk meneliti desain bentuk hull USV yang stabil untuk keperluan survei batimetri di perairan tenang.

Penelitian desain bentuk hull USV yang stabil untuk keperluan survei batimetri yang dilakukan baru merupakan langkah awal pembangunan suatu sistem USV untuk survei batimetri sehingga masih banyak batasan-batasan yang diterapkan dalam penelitian ini. Batasan-batasan penelitian meliputi: bentuk hull yang diteliti adalah monohull (satu lambung kapal); desain hull USV baru berupa potongan dua dimensi, yaitu: profile plan, half breadth plan, dan body plan; verifikasi untuk desain hull USV hanya mempertimbangkan kestabilan statik vertikal (tidak memperhitungkan pengaruh angin dan arus); kestabilan statik hanya untuk gerakan heave (diasumsikan hanya disebabkan oleh bobot total USV) dan roll sudut kecil; bobot yang diteliti merupakan bobot total USV beserta muatannya yang berupa perlengkapan survei batimetri; posisi penempatan muatan belum dipertimbangkan sehingga diasumsikan tidak adanya perubahan posisi pusat gaya berat; perhitungan massa kapal untuk dioperasikan di perairan tawar.

\section{METODOLOGI}

Penelitian desain bentuk hull USV yang stabil untuk keperluan survei batimetri ini hanya mempertimbangkan kestabilan statik. Artinya, pada penelitian ini belum dipertimbangkan faktor-faktor eksternal, seperti angin dan arus. Secara garis besar metodologi yang digunakan untuk penelitian dapat dilihat pada Gambar 1.

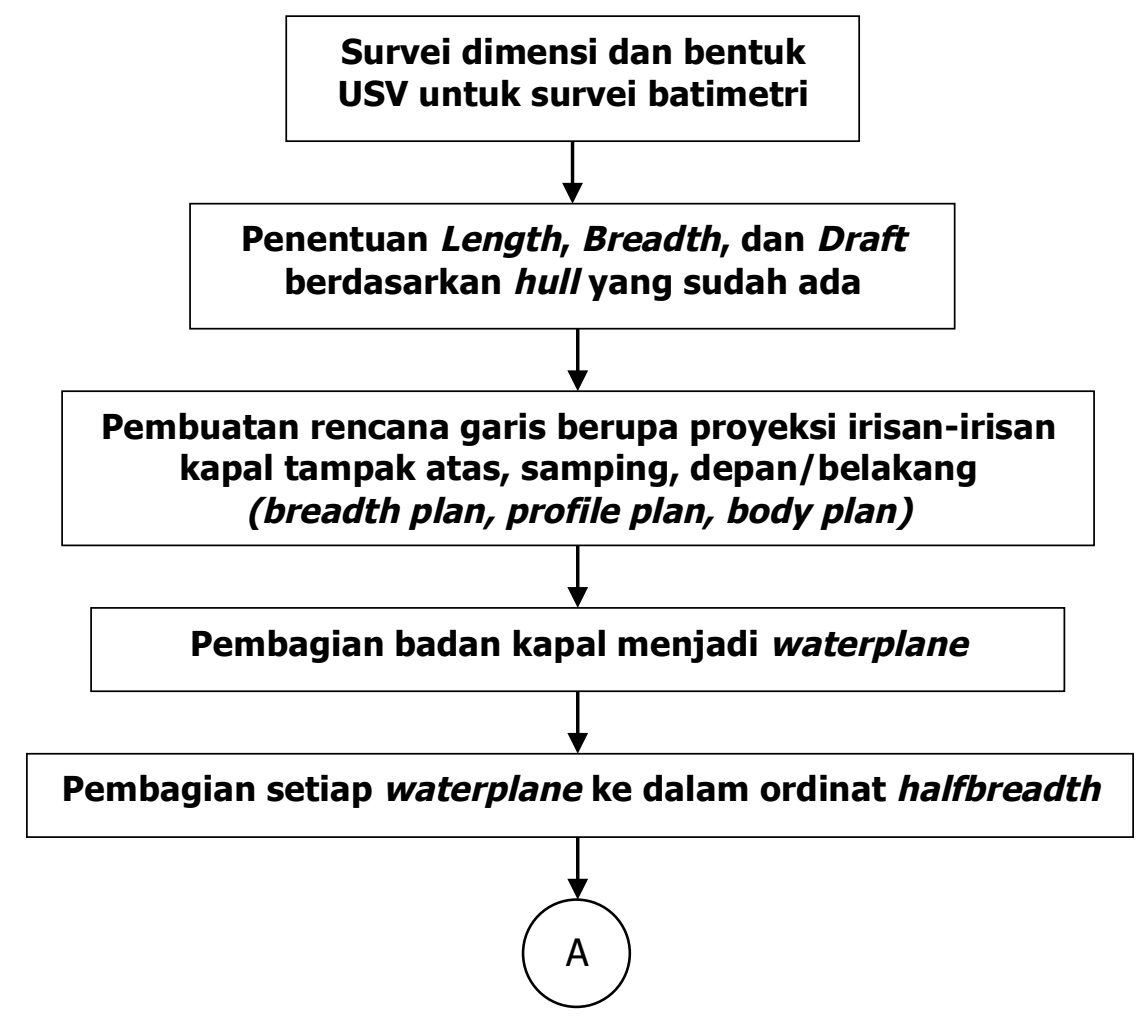

Reka Geomatika - 44 


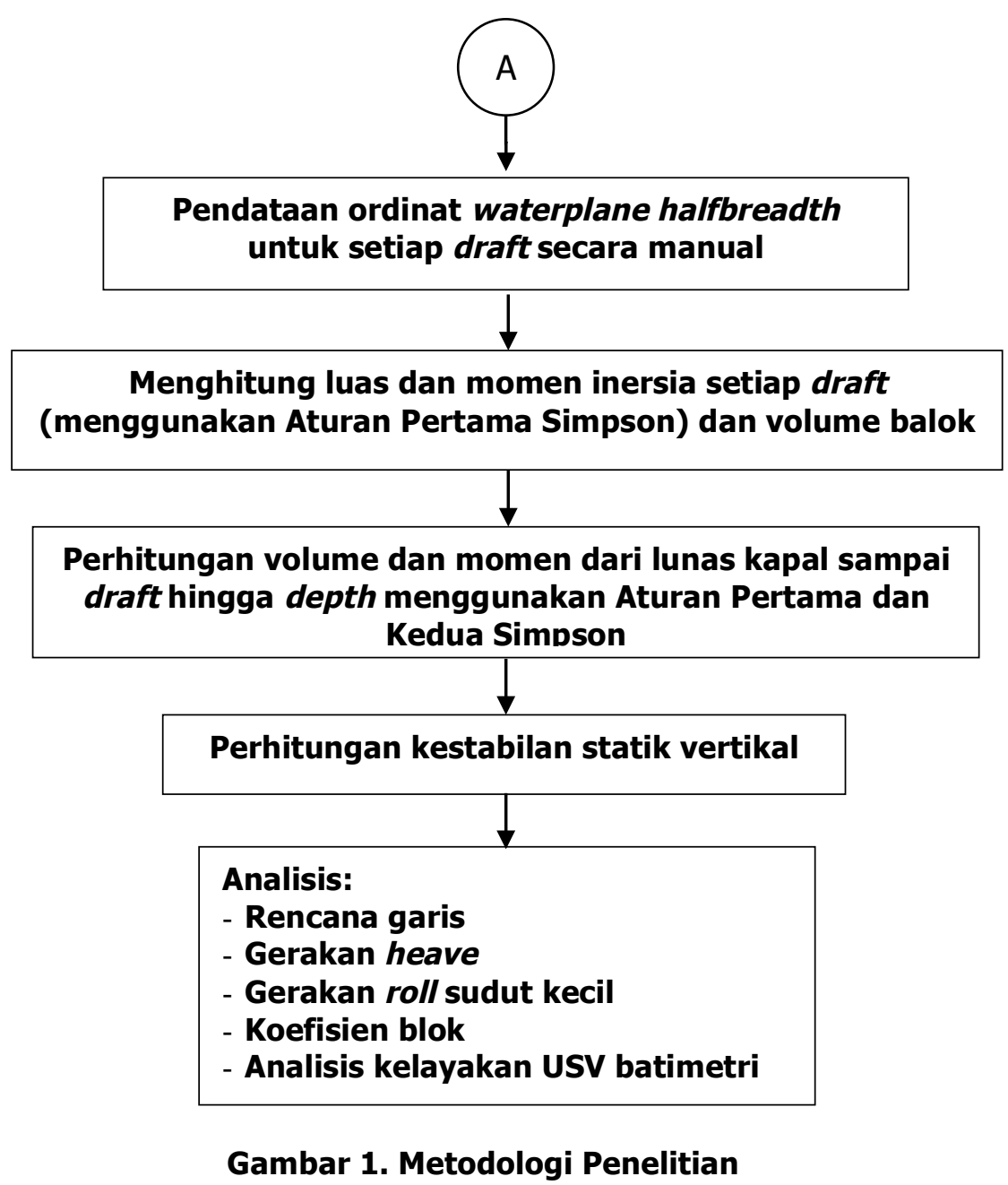

Pembuatan rencana garis hull dilakukan menggunakan Perangkat Lunak Freeship dan untuk mendapatkan ordinat di setiap waterplane dilakukan menggunakan Perangkat Lunak AutoCad. Pada penelitian ini dilakukan pertimbangan dari beberapa USV yang sudah aman beroperasi ditinjau dari dimensi dan bobot, yaitu Geomar (Robomarine, 2014), Z-1800 (Ocean Science, 2013), dan C-Stat (ASV Global, 2013).

\section{HASIL DAN PEMBAHASAN}

\subsection{Rencana Garis}

Rencana garis yang dihasilkan pada penelitian ini terdiri dari tiga tampak, yaitu tampak samping berupa profile plan (Gambar 2), tampak atas berupa halfbreadth plan (Gambar 3), dan tampak depan/belakang berupa body plan (Gambar 4). Kapal dibagi menjadi tiga garis air (waterline) mulai baseline hingga draft $(\mathrm{T})$ tertinggi (load waterline) dan sembilan belas ordinat membujur sepanjang badan kapal (after perpendicular hingga fore perpendicular).

Pada penelitian ini kapal didesain dengan bentuk $U$ bottom mulai dari bagian buritan hingga bagian depan seperti dapat dilihat pada Gambar 4a yang merupakan rencana garis body 
plan tampak belakang. Rencana ini dimaksudkan untuk mendukung stabilitas kapal saat penempatan peralatan pengukuran batimetri yang umumnya diletakkan di bagian buritan hingga sebagian haluan USV. Sementara itu, pada bagian haluan kapal didesain berbentuk V bottom seperti dapat dilihat pada Gambar 4b Menurut (Mardiyono, 1995) bentuk V bottom dimaksudkan agar kapal dengan kecepatan tertentu dapat membelah massa air dengan hambatan yang lebih kecil.

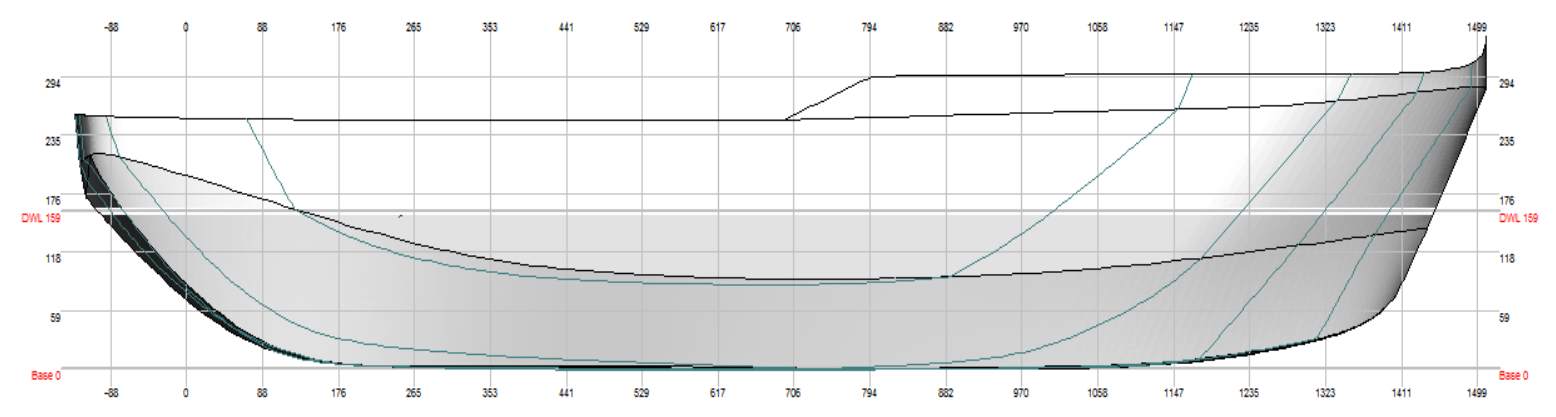

Gambar 2. Profile Plan

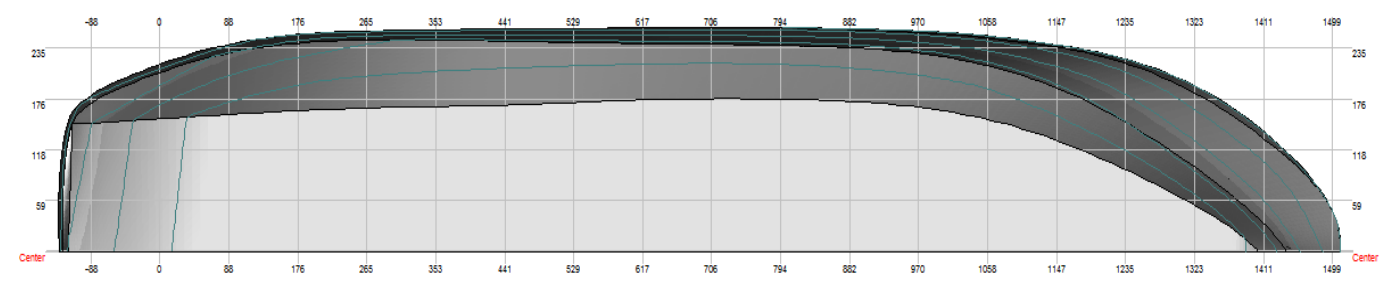

Gambar 3. Halfbreadth Plan

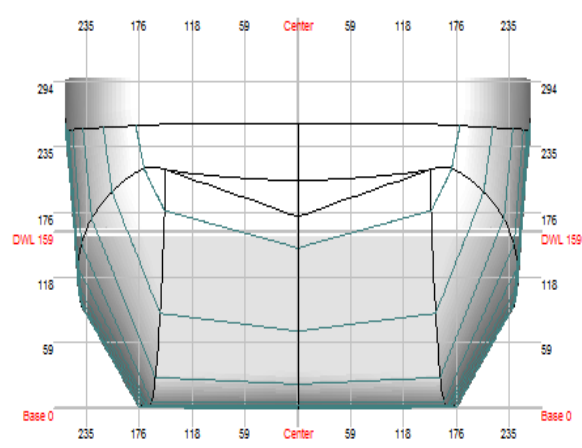

(a) Body plan tampak

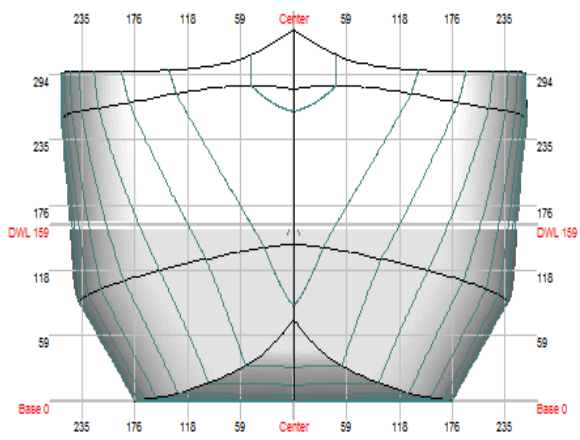

(b) Body plan tampak

Gambar 4. Body Plan

\subsection{Gerakan Heave}

Menurut Kanasin (2010), posisi pusat gaya apung (Titik B) akan berubah sesuai dengan kondisi bagian kapal yang tercelup di dalam air. Dalam hal ini dinyatakan oleh draft kapal. Pada penelitian ini posisi Titik B dari lunas kapal (KB) untuk setiap draft rencana dapat relatif terhadap pusat gayaberat dapat dilihat pada Gambar 5.

Pusat Gaya Apung B yang ideal untuk sebuah kapal adalah pusat gaya apung yang senantiasa berada di bawah Pusat Gayaberat G karena kondisi inilah yang meyebabkan kapal 
terapung. Pada penelitian ini posisi Titik G dari lunas kapal (KG) sebesar 0,131914432 meter. Seharusnya KG lebih besar dari KB. Berdasarkan Gambar 5 dapat dilihat bahwa KB untuk semua draft lebih kecil nilainya dari KG artinya Titik $G$ berada di atas Titik B yang menjamin draft yang didesain masih membuat kapal dalam kondisi terapung. Kondisi draft yang didesain dapat dicapai dengan desain bobot tertentu. Variasi bobot akan menyebabkan lebih naik atau turun yang menyebabkan terjadinya gerakan heave.

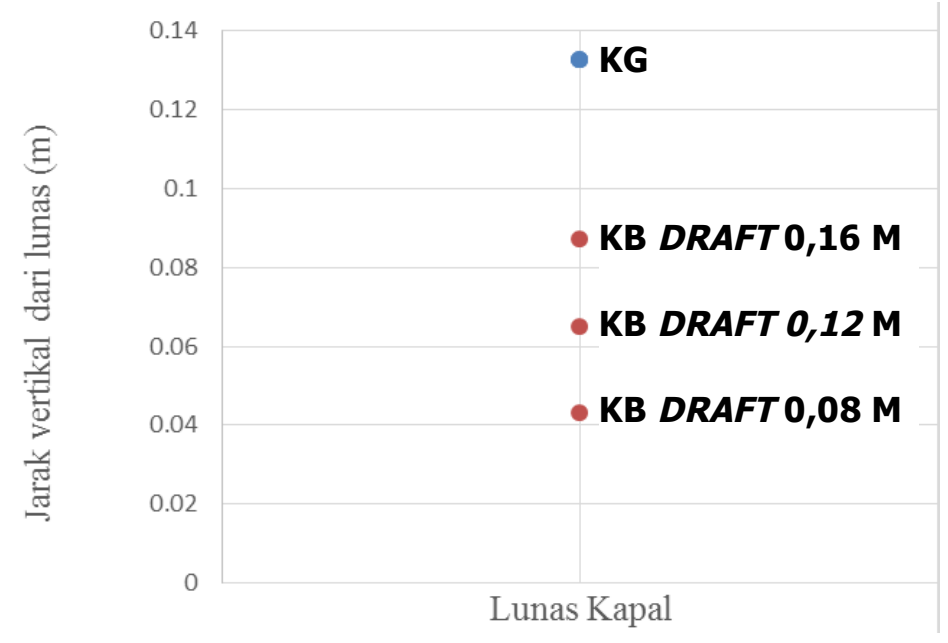

Gambar 5. Posisi KB Terhadap KG

Salah satu gerakan kapal di perairan adalah heave yang merupakan gerakan translasi terhadap sumbu Z (sumbu vertikal) di mana kapal mengalami gerakan naik turun secara vertikal. Pada penelitian ini gerakan heave diasumsikan hanya dipengaruhi oleh bobot kapal sehingga dilakukan penelitian terhadap bobot kapal dari variasi draft seperti pada Tabel 1 .

Tabel 1. Berat Kapal Sesuai Draft

\begin{tabular}{|c|c|}
\hline Draft Rencana (meter) & Bobot Kapal (kg) \\
\hline 0,16 & 83,3324088889 \\
\hline 0,12 & 59,2341900000 \\
\hline 0,08 & 36,3972622222 \\
\hline
\end{tabular}

Menurut Derrett dan Barras (1999), dalam law of floatation dinyatakan bahwa massa suatu benda yang terapung sama dengan massa air yang dipindahkan oleh bagian benda yang tercelup. Untuk kapal bagian yang tercelup dari lunas sampai ke draft. Pada penelitian ini diasumsikan kapal berada di air tawar yang memiliki densitas $1 \mathrm{ton} / \mathrm{m}^{3}$. Bobot kapal yang dimaksud dalam penelitian ini lebih pada terminologi massa daripada berat (weight). Pada Tabel 1 dapat dilihat bahwa bobot kapal maksimum (dalam arti kapal beserta muatannya maksimum) sekitar $83 \mathrm{~kg}$. Artinya kapal yang didesain pada penelitian ini tidak diperuntukkan untuk kapal yang berawak. Namun, bobot kapal beserta muatannya tidak boleh kurang dari $36 \mathrm{~kg}$. 


\subsection{Gerakan Roll Sudut Kecil}

Salah satu gerakan kapal di perairan adalah roll yang merupakan gerakan rotasi terhadap sumbu X (center line). Ketika terjadi roll bagian sisi kanan kapal bergerak ke sebelah bagian sisi kiri kapal yang terulang secara bergantian. Kestabilan kapal untuk gerakan roll dengan sudut kecil dapat dilihat dari jarak antara pusat gaya apung dan metasenter (BM). Sudut kecil menurut Kanasin (2010) adalah sudut yang tidak lebih dari $15^{\circ}$. Pada penelitian ini nilai BM untuk setiap draft dapat dilihat di Tabel 2 dan secara grafik dapat dilihat pada Gambar 6.

Tabel 2. Nilai BM Sesuai Draft

\begin{tabular}{|c|c|}
\hline Draft Rencana (meter) & BM (meter) \\
\hline 0,16 & 0,136282968 \\
\hline 0,12 & 0,143658772 \\
\hline 0,08 & 0,22248268 \\
\hline
\end{tabular}

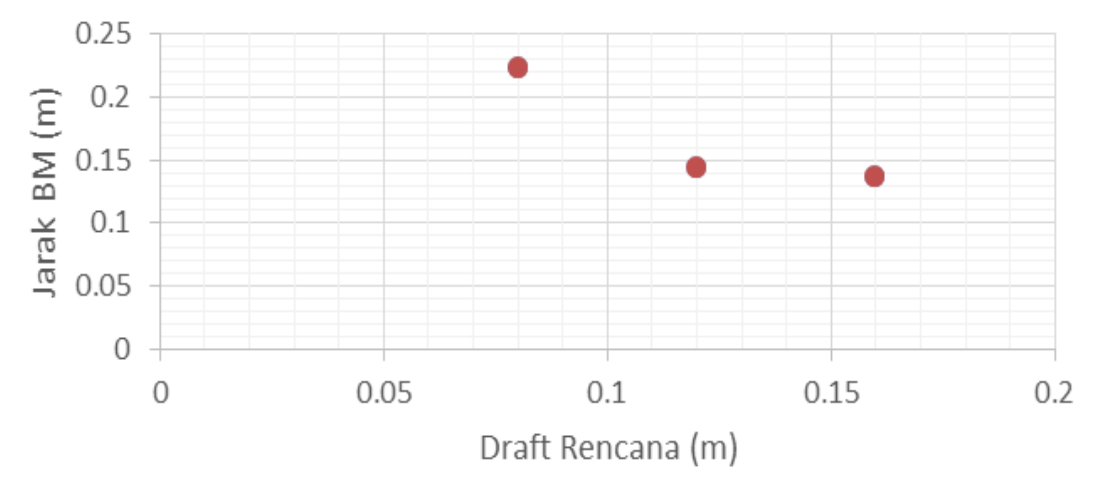

Gambar 6. Kondisi Kestabilan Tiap Draft Berdasarkan Harga BM

Berdasarkan Gambar 6 dapat dilihat semakin tinggi draft maka semakin kecil harga BM yang mengindikasikan bahwa waktu yang diperlukan kapal untuk tegak kembali lebih pendek. Dengan demikian Draft 0,16 meter jika terjadi roll sudut kecil memerlukan waktu yang lebih pendek untuk tegak kembali dibandingkan dengan draft rencana yang lain.

Menurut Kanasin (2010) stabilitas awal sebuah kapal adalah kemampuan dari kapal itu untuk kembali ke dalam kedudukan tegaknya semula sewaktu kapal miring pada sudut-sudut kecil. Di dalam membahas stabilitas awal sebuah kapal maka titik- titik penting dalam stabilitas kapal yang menentukan besar kecilnya nilai-nilai stabilitas awal adalah metasenter atau dikenal dengan Titik $M$ dari sebuah kapal, merupakan sebuah titik semu dari batas di mana pusat gayaberat (center of gravity) dikenal dengan Titik $\mathrm{G}$ dari sebuah kapal merupakan titik tangkap dari semua gaya-gaya yang menekan ke bawah terhadap kapal tidak boleh melewati di atasnya agar kapal tetap mempunyai stabilitas yang positif (stabil). Meta artinya berubah-ubah, jadi titik metasenter dapat berubah letaknya dan bergantung pada besarnya sudut senget. Apabila kapal senget pada sudut kecil (tidak lebih dari $15^{\circ}$ ) maka Pusat Gaya Apung B (buoyancy) bergerak di sepanjang busur di mana Titik M merupakan titik pusatnya di bidang tengah kapal (center of line) dan pada sudut senget yang kecil ini perpindahan letak Titik M masih sangat kecil, sehingga masih dapat dikatakan tetap. Nilai GM inilah yang menunjukkan keadaan stabilitas awal kapal atau jika kapal memiliki cukup nilai GM maka akan menjamin adanya momen pengembali untuk keadaan stabilitas kapal selama pelayaran nanti. Pada penelitian ini hasil kondisi kestabilan untuk setiap draft rencana yang diwakili oleh harga GM dapat dilihat pada Tabel 3 dan secara grafik dapat dilihat pada Gambar 7. KG

$$
\text { Reka Geomatika - } 48
$$


adalah jarak pusat gayaberat dari lunas kapal, KM adalah jarak metasenter dari lunas kapal, sedangkan GM adalah jarak antara pusat gayaberat dan metasenter.

Tabel 3. Kondisi Kestabilan Tiap Draft Rencana Berdasarkan Harga GM

\begin{tabular}{|c|c|c|c|}
\hline Draft Rencana (m) & KG (m) & KM (m) & GM (m) = KM -KG \\
\hline 0,16 & 0,13245637 & 0,2233429968 & 0,090886560 \\
\hline 0,12 & 0,13245637 & 0,2085687095 & 0,076112273 \\
\hline 0,08 & 0,13245637 & 0,2654683989 & 0,133011962 \\
\hline
\end{tabular}

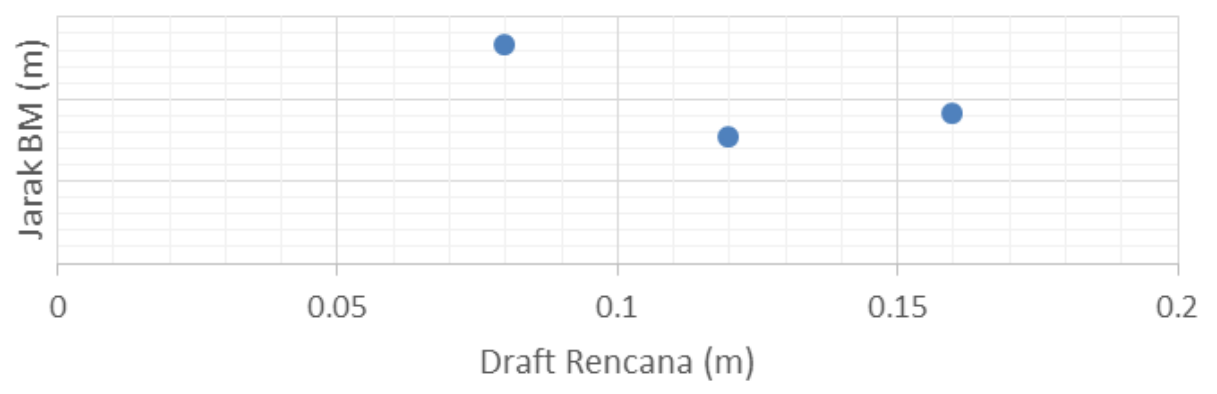

Gambar 7. Kondisi Kestabilan Tiap Draft Berdasarkan Harga GM

Kondisi kestabilan yang diharapkan adalah kestabilan positif di mana metasenter berada di atas pusat gayaberat dilihat dari lunas kapal yang diwakili oleh harga GM positif yang merupakan indikasi jika terjadi kapal senget maka kapal akan tegak kembali. Berdasarkan Gambar 7 dapat dilihat bahwa semua draft yang direncanakan memiliki kestabilan positif, artinya kapal tidak akan terbalik atau dalam keadaan tetap miring. Namun, makin tinggi draft makin kecil nilai GM yang mengindikasikan makin jarangnya terjadi roll. Menurut Budzik (2010) kapal dengan nilai GM yang kecil merupakan kapal yang bersifat tender yang lebih jarang terjadi gerakan roll. Dengan demikian Draft 0,12 meter bersifat lebih tender dibandingkan dengan draft rencana lain.

\subsection{Koefisien Blok}

Coefficient of fineness kapal yang biasa disebut koefisien kegemukan kapal mencerminkan bentuk badan kapal. Dari beberapa koefisien bentuk kapal, nilai koefisien blok $\mathrm{C}_{\mathrm{b}}$ yang paling sering dipakai dalam menentukan tingkat kegemukan kapal, karena nilai ini mencerminkan bentuk badan kapal yang tercelup di dalam air. Pada penelitian ini koefisien blok untuk kapal dapat dilihat pada Tabel 4.

Tabel 4. Koefisien Blok

\begin{tabular}{|c|c|c|l|}
\hline Parameter & Draft 0.08 & Draft 0,12 & Draft 0.16 \\
\hline Koefisien Blok $\left(C_{b}\right)$ & 0,689492522 & 0,711872736 & 0,6755711426 \\
\hline
\end{tabular}

Nilai $C_{b}$ dari variasi draft berada dalam kisaran nilai 0,6755711426 sampai dengan 0,711872736. Menurut Gaythwhaite (2004), kapal cepat memiliki koefisien blok yang kecil. Jadi, artinya makin besar nilai koefisien blok maka makin lambat kapal melaju. Koefisien blok yang bernilai dalam rentang 0,68 sampai dengan 0,71 dikategorikan untuk kapal kargo, di mana kapal ini tidak memerlukan kecepatan tinggi untuk menjaga muatan yang diangkut. Kapal kargo merupakan kapal yang berdimensi besar. Kapal yang didesain pada penelitian ini 
memiliki koefisien seperti kapal kargo yang tidak didesain untuk kapal cepat, namun dengan dimensi yang kecil lebih untuk USV.

\subsection{Kelayakan Peruntukan USV Batimetri}

Kapal yang dirancang pada penelitian ini didesain sebagai kapal tanpa awak (USV) untuk survei batimetri di perairan dangkal yang tidak bisa dilakukan oleh kapal ukuran normal. Kapal yang didesain sudah memenuhi syarat kestabilan statik berdasarkan nilai BM dan GM. Berikut ini akan dianalisis mengenai dimensi, bobot, dan desain kapal lambat (berdasarkan koefisien blok) seperti dapat dilihat pada Tabel 5 .

\section{Tabel 5. Analisis Kelayakan USV Survei Batimetri}

\begin{tabular}{|l|l|}
\hline Dimensi : & \\
- L (length) & 1,641 meter \\
- B (breadth) & 0,517 meter \\
- D (depth) & 0,260 meter \\
\hline Bobot kapal dan muatan & $36-83 \mathrm{~kg}$ \\
\hline Koefisien Blok & $0,68-0,71$ \\
\hline
\end{tabular}

Dilihat dari dimensi dan bobot kapal beserta muatannya kapal yang dirancang ini berukuran kecil sehingga tidak diperuntukkan untuk kapal yang berawak sehingga lebih cocok untuk kapal tanpa awak (USV). Untuk keperluan survei batimetri berorde khusus diperlukan kerapatan titik yang tinggi sehingga diperlukan USV dengan kecepatan rendah. Dilihat dari koefisien blok yang cukup besar (lebih dari 0,5 ) dikatogerikan kapal yang didesain merupakan kapal berkecepatan rendah sehingga cocok untuk keperluan survei batimetri. Namun, kapal yang didesain ini baru diuji kestabilan statiknya untuk dua gerakan, yaitu heave dan roll untuk sudut kecil. Masih perlu diuji untuk gerakan roll sudut yang besar dan untuk empat gerakan yang lain, yaitu surge, pitch, yaw, dan sway. Hal yang cukup penting lagi adalah masih perlu pengujian kestabilan dinamik di mana faktor-faktor eksternal seperti pertimbangan angin dan arus.

\section{KESIMPULAN}

Dalam penelitian ini hull didesain dengan dimensi panjang 1,64 meter; lebar 0,52 meter; dan tinggi total 0,26 meter di mana dua pertiga hull bagian bawah buritan berbentuk $U$ dan sepertiga hull bagian bawah haluan berbentuk V. Draft rencana 0,08; 0,12; dan 0,16 meter semuanya memiliki kestabilan positif (nilai GM positif) dan memiliki kondisi pusat gaya berat berada di atas pusat gaya apung yang yang menjamin kapal dalam kondisi terapung. Draft 0,12 meter bersifat lebih tender (memiliki gerakan roll lebih jarang) dan Draft 0,16 meter memiliki jarak titik apung ke metasenter (BM) paling kecil (jika terjadi roll sudut kecil memerlukan waktu yang lebih pendek untuk tegak kembali). Bobot kapal beserta muatan direkomendasikan antara 36 - $83 \mathrm{~kg}$. Koefisien blok berkisar 0,68 - 0,71 dikategorikan sebagai kapal yang didesain bukan untuk kapal cepat. Dengan demikian dilihat dari dimensi dan bobot kapal beserta muatannya kapal yang dirancang ini berukuran kecil sehingga tidak diperuntukkan untuk kapal yang berawak sehingga lebih cocok untuk kapal tanpa awak (USV) dan memiliki koefisien blok yang cukup besar (lebih dari 0,5) yang dikategorikan sebagai kapal berkecepatan rendah sehingga cocok untuk keperluan survei batimetri. 


\section{UCAPAN TERIMA KASIH}

Terima kasih kepada PT Robomarine Indonesia, Bandung atas kesediaan memberikan penjelasan mengenai USV hidrografi yang telah dibangun. Terima kasih pula kepada Jimmy Murhas dan Kania Rahmanti atas kontribusi teknis dalam pengumpulan dan pengolahan data.

\section{DAFTAR PUSTAKA}

ASV Global. (2013). C-Stat Station Keeping Buoys. ASV Global, Mempshire, England.

Budzik, P. (2014). Ship Form. Dipetik 11 Desember 2014, dari http:// paulbudzik.com/current-projects/Enterprise\%20Scratch/ShipForm.pdf

Derrett, D. R. dan Barras, C. B. (1999). Ship Stability For Masters and Mates. Butterworth Heinemann, Hinacre House, Jordan Hill, Oxford.

Duranti, P. dan Romano, A. (2012). Autonomous Unmanned Surface Vessels for Hydrographic Measurement and Environmental Monitoring. Hydrographic Technologies, Rome, Italy.

Gaythwaite, J. W. (2004). Design of Marine Facilities for the Berthing. Mooring and Repair of Vessels. American Society of Civil Engineering.

Kanasin, H. (2010). Karakteristik dan Operasi Angkutan Sungai Danau dan Penyeberangan. Direktorat Angkutan Sungai Danau dan Penyeberangan.

Mardiyono, A. (1995). Studi Tentang Desain Kapal Cantring di Labuan. Departement of Marine Fisheries IPB, Bogor.

Oceanscience. (2013). Z-Boat 1800 Remote Control Hydrographic Survey Boat. Oceanscience, California, USA.

Perbani, N.M.R.R.C. (2014). Pembangunan Sistem Penentuan Posisi dan Navigasi Berbasiskan Sistem Unmanned Surface Vehicle (USV) untuk Survei Batimetri. Jurnal Itenas Rekayasa No.1 Vol. XVIII, Januari 2014, Bandung.

Robomarine. (2014). Geomar Survey Boat. PT. Robomarine Indonesia, Bandung. 